\title{
ETHNOMEDICINALLY IMPORTANT PLANTS USED BY THE LOCAL PEOPLE OF AL GALABAT LOCALITIES, GEDAREF STATE, SUDAN
}

\author{
Yahya Sulieman ${ }^{1}$ \\ ${ }^{1} \mathrm{PhD}$ Research Scholar, \\ Medicinal and Aromatic Plants research \\ Institute, \\ National Council for Research, \\ Khartom, Sudan
}

\author{
Haidar Abd Algadir ${ }^{2}$ \\ ${ }^{2}$ Assistant Professor, \\ Department of biology, \\ Faculty of Science, \\ Albaha University, \\ Saudi Arabia P.O.
}

\author{
Ikram Madani $^{3}$ \\ ${ }^{3}$ Associate Professor, \\ Department of Botany, \\ University of Khartoum, \\ Faculty of Science,
}

Article DOI: $\underline{\text { https://doi.org/10.36713/epra5968 }}$

\begin{abstract}
This research aims to document the medicinal plants used by the local people in two localities of El Gadaref state in eastern Sudan. Information was obtained during several visits using a semi-structured questionnaires in group discussions at herbal medicine practitioners homes, market, and healers shops. Most of the information was obtained from respondents of age 51 to 65 years. The study documented 79 species belonging to 36 families used to treat various ailments. The most utilized plant families were Leguminosae (45\%) followed by Combretaceae (11\%). $7 \%$ of the total plants used belongs to Asteraceae, Capparaceae, and Solanaceae. This study document the use of Martynia annua fruits to treat tumors and dysentery for the first time in Sudan. Common treated diseases are abdominal pains, unary tract infections, fever, and malaria. Further pharmacological research studies are recommended to identify the active chemical components in the reported plants.
\end{abstract}

KEYWORDS- Medicinal plants; local people; Gadarif state ; Sudan

\section{INTRODUCTION}

Ethnobotany explains the relationship between people of a given community or society, the environment and the plant diversity in that particular community (Osawaru, \& Dania-Ogbe, 2010). Ethnobotanists focus primarily on how plants are used, managed and perceived across human societies. This includes use for food, clothing, medicine, dyes, construction, cosmetics and more (Acharya and Shrivastava, 2008). Modern ethnobotanical approaches are significant in highlighting locally important plant species, particularly for new crude drugs. They have been broadened to include data not only from anthropology and botany, but also from pharmacology and phytochemistry (Cotton 1997). Documentation of the indigenous knowledge about medicinal values of plant species, provided various vital modern drugs (Cox and Balick, 1994).

In Sudan, medicinal plants used by local people of certain districts were documented as part of medicinal and aromatic plants and tradition medicine research institute (MAPTMRI) projects. Areas covered by MAPTMRI studies include Erkawit (El Ghazali, 1986), Nuba mountains (El Ghazali et al, 1987), White Nile (Ghazali, 1994), North Kordofan (Ghazali, 1997), and Ingassana (Ghazali, 2003). Musa et al 2011 and Gibreel 
et al 2013 Studied the medicinal plants in the Blue Nile State, Haidar et al. 2013 documented the medicinal and aromatic plants in Jabel El dair national reserve, and Ahmed et al 2014, reported the ethnomedicinally important plants in Ga"ab El Lagia Oasis in the northern Sudan. Ahmed et al 2020 documented the traditional use of medicinal plants among the Barti tribe community in Fangoga area in Sennar State. This study is confined to Galabat localities of El Gedaref state in eastern Sudan. There is no previous ethnobotanical reports documented for this area which is inhabited by ethnic groups representing different tribes.

\section{MATERIALS AND METHODS 2.1. Study area}

This study was conducted in two localities of El Gadaref state which is a regional state located in the eastern part of Sudan ( longitudes $33-36^{\circ} \mathrm{E}$ and latitudes $13-16^{\circ} \mathrm{N}$ ). It is bordered by Ethiopia to its East, Kassala and Khartoum State to the North, El Gezira State to the West and Sennar State to the South. The total area of the State is approximately $71,000 \mathrm{~km}^{2}$. El Gadaref State is divided into ten administrative localities which include Gadaref, Central Gadaref, Alrahad, Alfaw, Eastern Algalabat, Western Algalabat, Alfashqa, Albutana, Galaa alnahal and Alquresha (OCHA, 2012). This study is confined to Eastern Algalabat and Western Algalabat localities ( Figure 1). According to the vegetation cover map of Sudan, wooded Gadaref state is located in the zone of low rainfall woodland savanna (Harison and Jackson, 1958). The rainfall ranges between $300 \mathrm{~mm}$ in the North to more than $800 \mathrm{~mm}$ in the South. (Sulieman and Elagib, 2012). Highest temperature is recorded in April when the mean daily is $40{ }^{\circ} \mathrm{C}$ (Elsafori, 2000). The total population exceeds 4.3 million people, with an annual growth rate of $3.87 \%$. $80.5 \%$ of the population lives in rural areas (Sulieman and Buchroithner, 2009).

\subsection{Ethnobotanical data collection survey}

Eethnobotanical information was obtained during several visits in the period 2014-2016. using a semistructured questionnaires and from group discussions organized at herbal medicine practitioners homes, market, and healers shops with the assistance of some local people known to the authors. Documentation was taken from a total of 31 informants. Most of the information was obtained from respondents of age 51 to 65 years. Informants were asked about the plants and the harvested parts they use to cure the prevalent diseases, methods of preparing the herbal remedy, and administrative details.

\section{Results and discussion}

In this study, 79 species belonging to 36 families were documented as medicinal plants used by the local people who are mostly relay on traditional medicine in their healthcare system Table1. The local people show high knowledge of understanding of the local vegetation and knew the proper time and places to collect the medicinal plants from their natural habitats. Analysis of the information showed that most of the medicinal plants used in this area belong to the Leguminosae ( $45 \%$ ) with six species belong to genus Acacia, followed by Combretaceae (11\%), and equal number of species from the families Asteraceae, Capparaceae, and Solanaceae were reported as $7 \%$ of the total plants. Figure 2. Ahmed et al., (2020) conducted a similar study in Fangoga area in Sinnar state and reported that Leguminosae have the highest number of medicinal plants species used by the local people. It is reported by many authors that fruits decoction of Acacia nilotica is an effective remedies to treat cough, sour throat, and fever in different areas in Sudan (El Ghazali 1986; El Ghazali et al. 1987; Musa et al. 2011; and Ahmed et. al. 2014). Treatment of diarrhea by eating of the fruits of Adansonia digitata and using of root decoction of Hydnora abyssinica to treat dysentery were also reported for the local people in northern Kordofan (Ghazali, 1997). Eating of the whole plant of Aristolochia bracteolate to treat stomach pains is also reported by El Ghazali et al 1987 for the local people in the Nuba mountain area. Using of bark decoction and poultice, followed by the whole plant ( as raw) were the most treatments used frequently by the locals. Seeds were rarely used. Figure 3.These results were in agreement with previous studies conducted in this region by Bayafers, 2000 and Endalew, 2007. The main preparation methods of herbal remedies used in this study were decoction ( $37 \%$ ), maceration (26\%) followed by Powder (15\%), poultice ( $14 \%$ ), burnt and using of whole plant as raw (4\%) figure 4 . Some applications were also prepared as a mixture of plants with other ingredients such as salt, sugar and pepper as additives to improve the taste. The commonly occurred aliments and parasitic diseases in the study area were abdominal pains, unary tract infections, fever, rheumatism, malaria and tapeworm. This study documented for the first time in Sudan, the use of Martynia annua fruits decoction and maceration to treat dysentery and tumors respectively. 


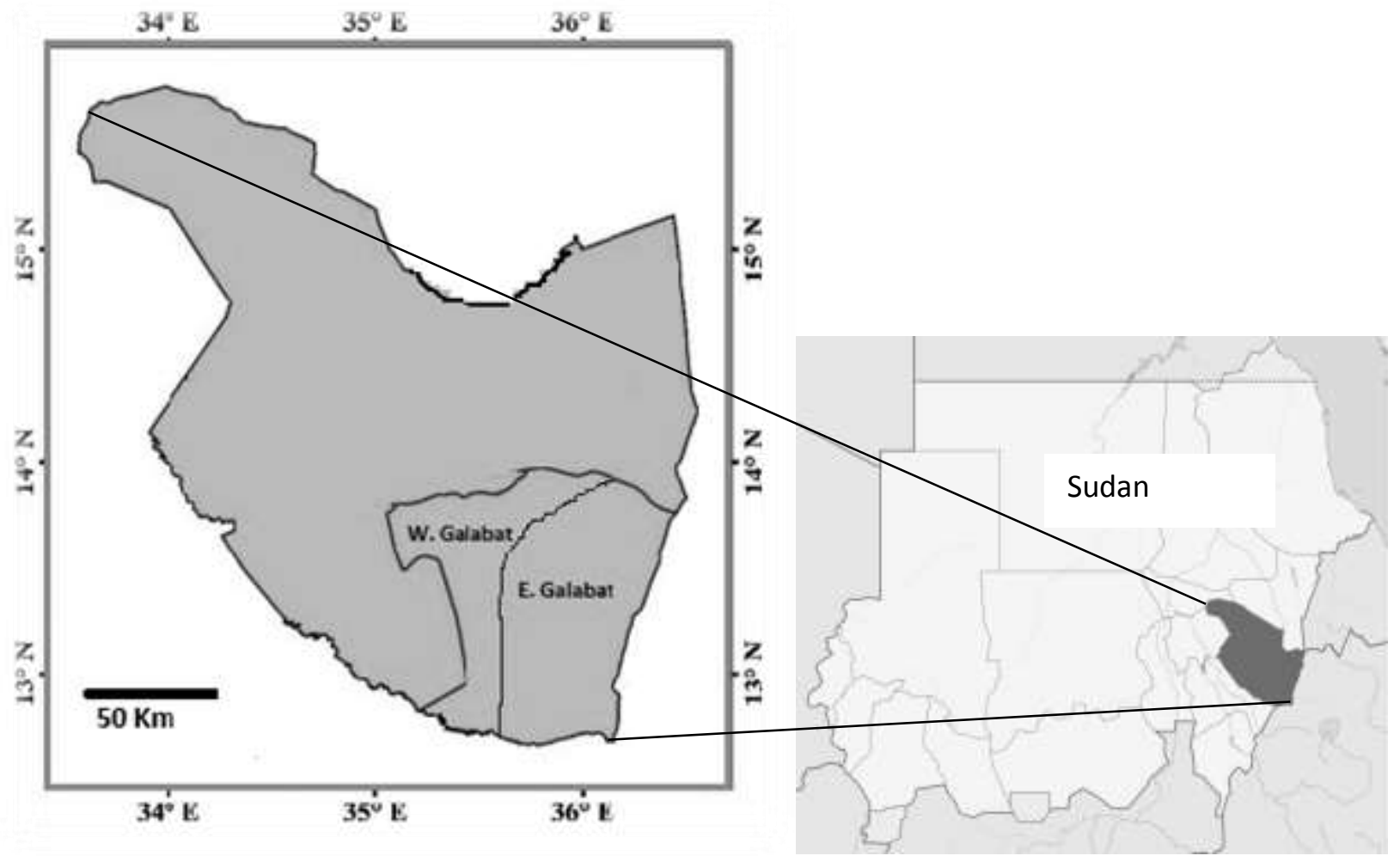

Figure 1. Location of eastern and western Galabat localities, Gadarif state, Sudan

Table 1: List of Medicinal plants used by local people in Galabat localities, Gadarif state, Sudan

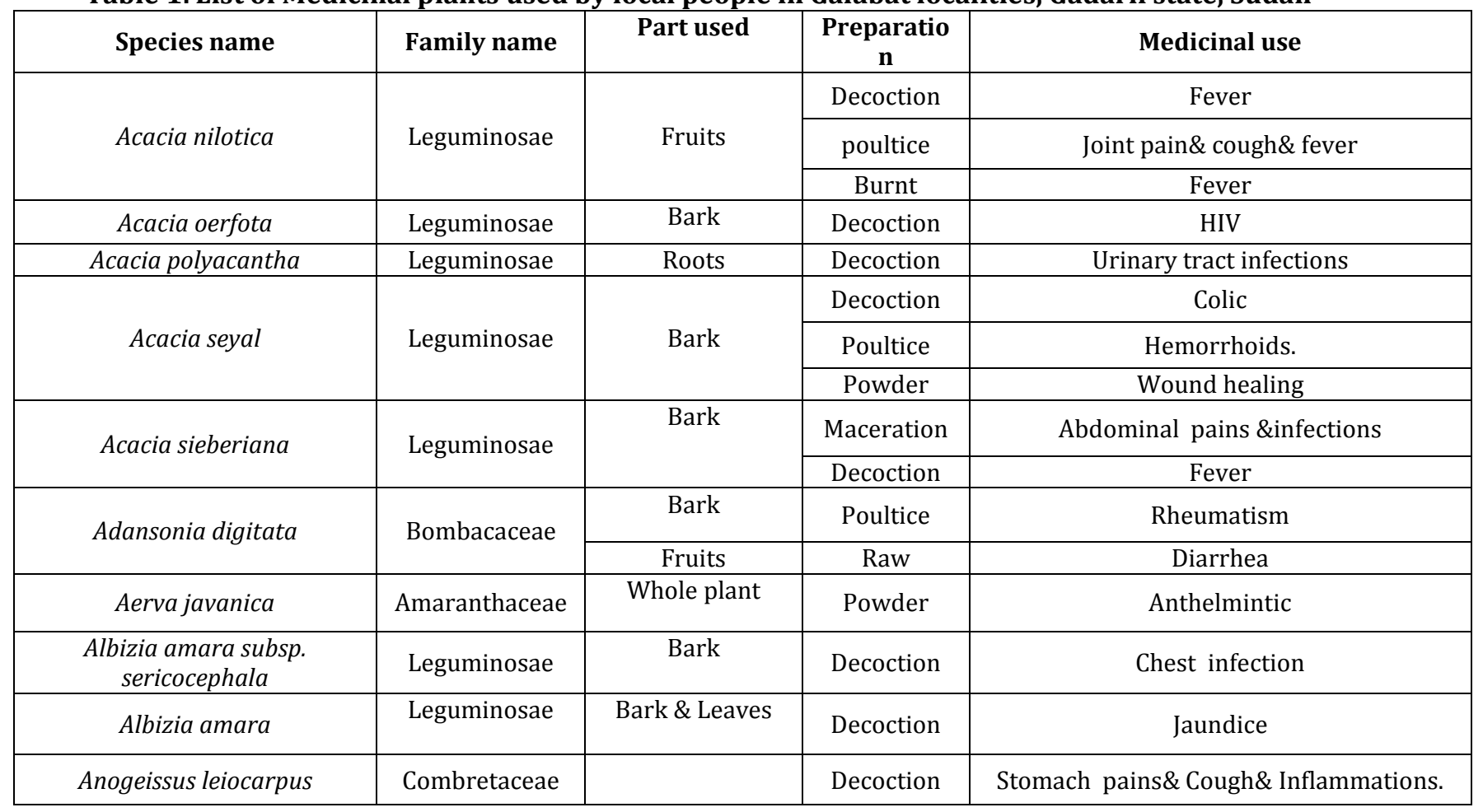


ISSN (Online): 2455-3662

EPRA International Journal of Multidisciplinary Research (IJMR) - Peer Reviewed Journal

Volume: 6 | Issue: 12 |December 2020 || Journal DOI: 10.36713/epra2013 || SJIF Impact Factor:_7.032 ||ISI Value: 1.188

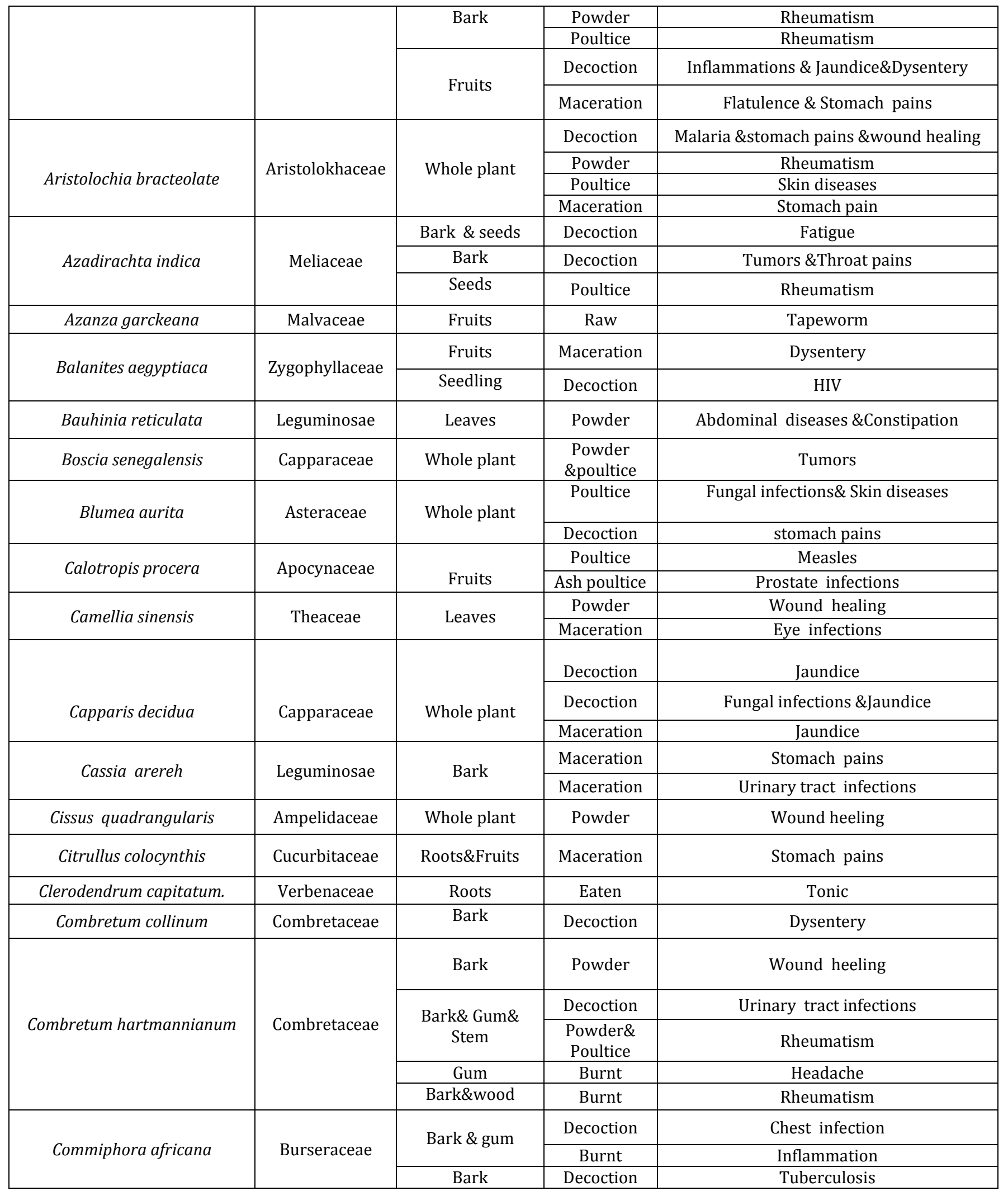


ISSN (Online): 2455-3662

EPRA International Journal of Multidisciplinary Research (IJMR) - Peer Reviewed Journal

Volume: 6 | Issue: 12 |December 2020 || Journal DOI: 10.36713/epra2013 || SJIF Impact Factor:_7.032 ||ISI Value: 1.188

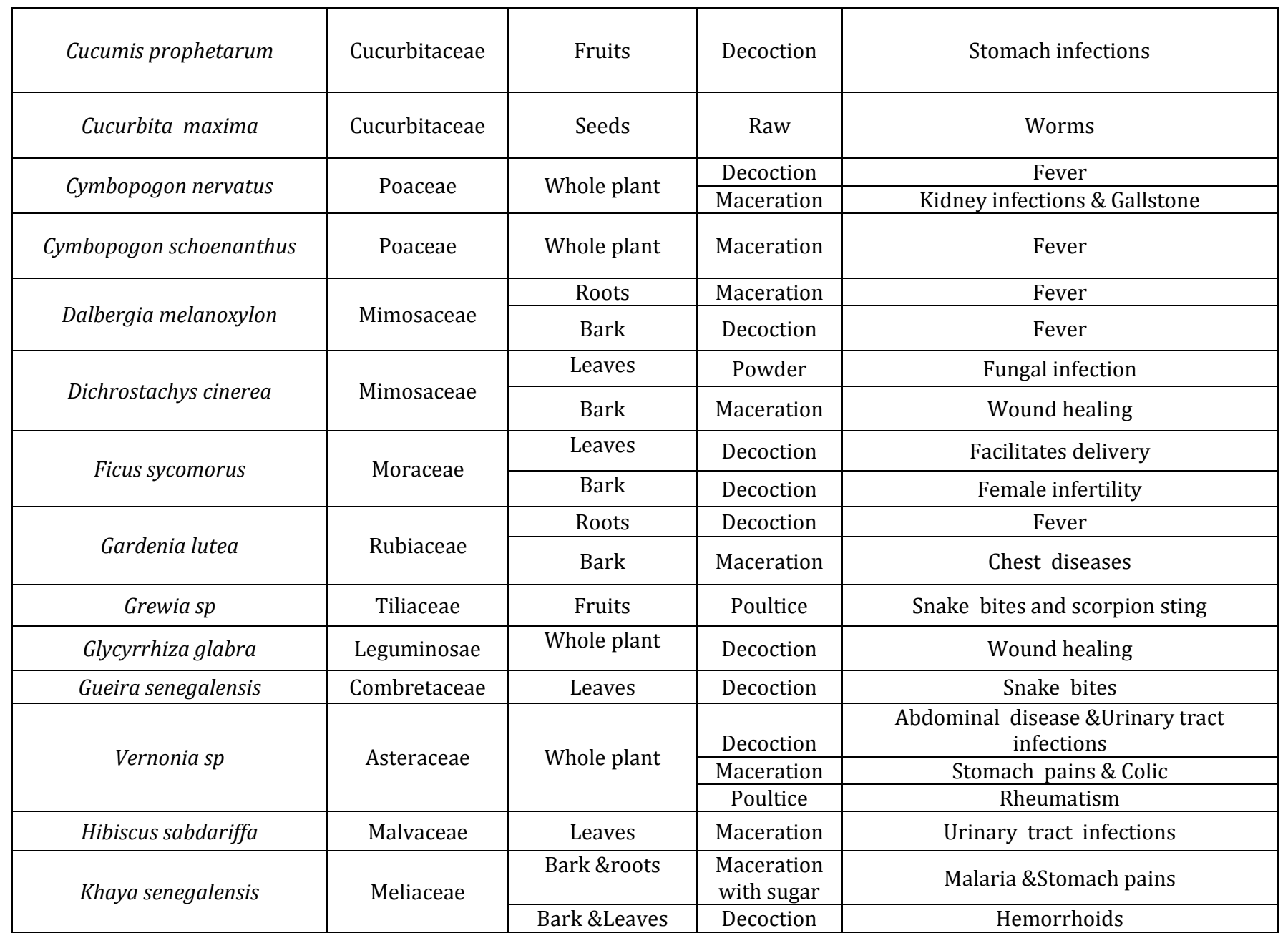

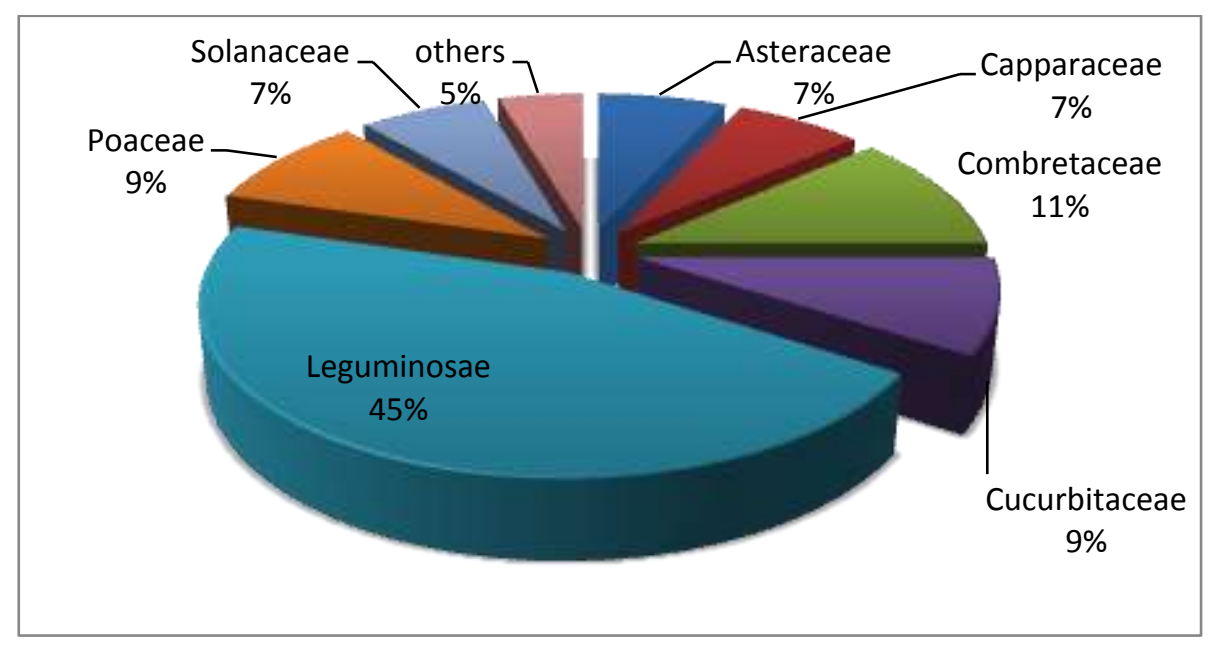

Figure 2. The percentages of medicinal species in each family 


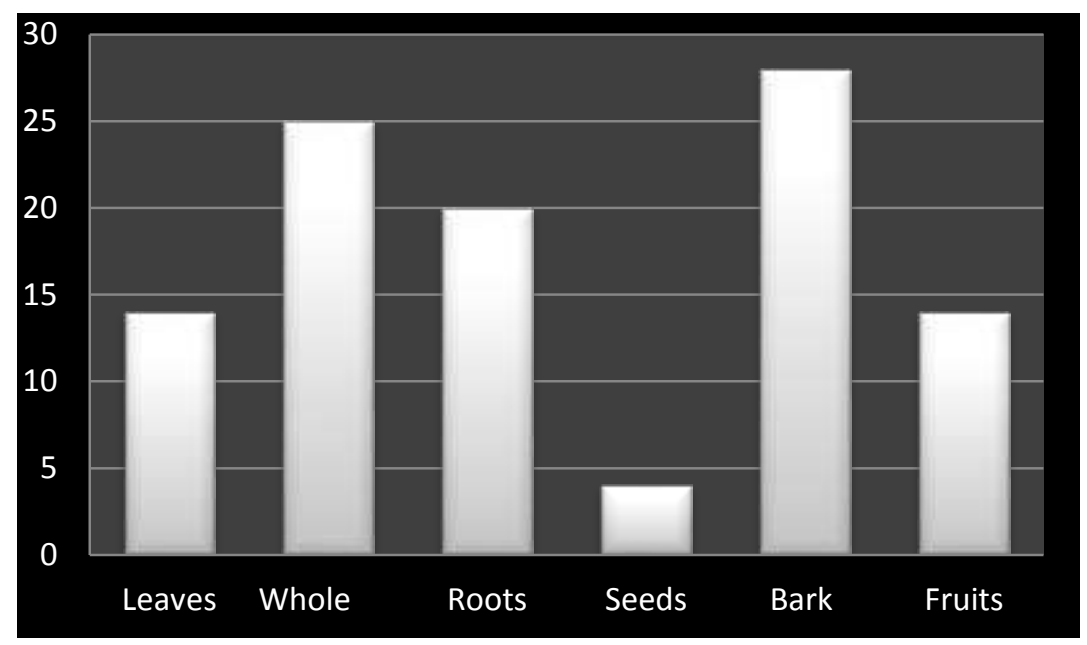

Figure 3. Different plant parts used from the medicinal plants of the study area

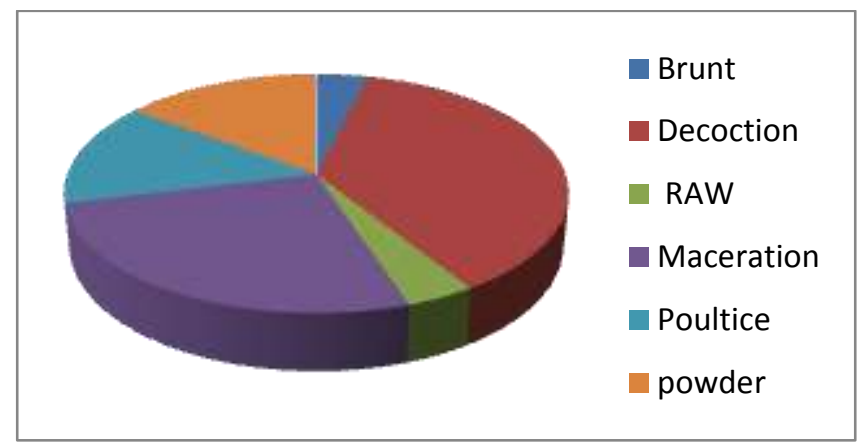

Figure 4. The main preparation methods of herbal remedies used in the study area

\section{REFERENCE}

1. Acharya, D. \& Shrivastava, A. (2008) Indigenous Herbal Medicines: Tribal Formulations and Traditional Herbal Practices. Aavishkar Publishers Distributor. Jaipur, 440.

2. Ahmed I. M., Tahir, Y. F., Nour, S.M. \& Suliman, M. A. (2020) Traditional use of medicinal plants among the Barti tribe community in Fangoga area, Sennar State, Sudan. Tropical Plant Research 7(2): 517-521

3. Ahmed, I. M. , Tahir, Y. .F \& Nour, S. M. (2014) Ethnobotanical study of medicinal plants used by El Kababish tribe in Ga'ab El Lagia Oasis, West Dongla (Sudan). Nyame Akuma Bulletin 82: 91-99

4. Cotton, C.M. (1997). Ethnobotany, Principles and Applications. Wiley \& Sons, UK

5. Endalew, A.(2007). Use and Management of Medicinal Plants by indigenous People of Ejaji Area (Chelya Wereda) West Shewa, Ethiopia: An
Ethnobotanical Approach. M.Sc. Thesis. Addis Ababa, Ethiopia.

6. El Ghazali, G.E.B. (1986) Medicinal Plants of Sudan Part I. Medicinal Plants of Erkowit. Khartoum: National Council for Research.

7. El Ghazali, G.E.B., Bari, E.A., Bashir, A.K \& Salih, A.(1987) Medicinal Plants of Sudan Part II. Medicinal Plants of Eastern Nuba Mountains. Khartoum: National Council for Research.

8. El Ghazali, G.E.B., El Tohami, M.S. \& El Egami, A.A.B. (1994) Medicinal Plants of the Sudan Part III. Medicinal Plants of White Nile Province. Khartoum: National Council for Research.

9. El Ghazali, G.E.B., El Tohami, M.S., El Egami, A.A., Abdalla, W.E. \& Galal, M.(1997) Medicinal Plants of the Sudan Part IV. Medicinal Plants of North Kordofan. Khartoum: National Council for Research.

10. El Ghazali, G.E.B., Khalid, H.E., El Tohami, M.S., Abdalla, W.E. \& Yagi, S.M.A. (1998) Medicinal 
Plants of the Sudan, Part VI. Medicinal Plants commonly used in Khartoum State. Khartoum: National Centre for Research

11. El Ghazali, G.E.B., Abdalla, W.E., Khalid, H.E., Khalafalla, M.M. \& Hamad, A.A. (2003) Medicinal Plants of the Sudan Part V. Medicinal Plants of Ingassana Area. Khartoum: National Council for Research.

12. Harrison, M. N. \& Jackson, J.K. (1958). Ecological Classification of Vegetation of the Sudan. Sudan Forest Department Bulletin (4): 45pp

13. Haidar,A.M., Khaled,H,S., Elsadiq, $W$ \& Salwa, $M$. .(2013). An ethnobotanical study of medicinal and aromatic plants in jabel el dair national reserve, Northern kordofan state, Sudan, 15th NAPRECA symposium, Khartoum, Sudan.

14. OCHA, 2012. Sudan: Gedaref State Administrative Map. September, from https: \&\&reliefweb.

int\&sites\&reliefweb.int\&files\&resources\&sud04_g edaref_state_referencemap_a1_16sep12.pdf.

15. Osawaru, M.E. \& Dania-Ogbe, F.M. (2010). Ethnobotanical studies of West African okra, Abelmoschus caillei (A. Chev) Stevels from some tribes of south western Nigeria. Science World Journal, 5(1): 36- 42.

16. Musa, M.S., F.E. Abdelrasool, F.E. Elsheikh, E.A., Ahmed, L.A.M.N., Mahmoud, A.E. \& Yagi, S.M. (2011) Ethnobotanical study of medicinal plants in the Blue Nile State, South-eastern Sudan. Journal of Medicinal Plants Research 5(17): 4287-4297.

17. Gibreel, Haytham H.,M.Y.Kordofani, Warrag \& H.O.Ahmed (2013)Medicinal value and ecotaxonomy of the flora of Blue Nile State. Journal of Chemical and Pharmaceutical Research $5(2): 36-43$

18. Elsafori, A.K. (2000). A study on the flora of Al faw Hill Central Sudan, Sudan M.Sc. thesis, University of Khartoum, Khartoum, Sudan.

19. Sulieman, H. \& Buchroithner, M.. (2009). Degradation and abandonment of mechanized rain-fed agricultural land in the Southern Gadarif region, Sudan: the local farmers' perception. Land Degrad. Dev. (20): 199-209. Retrieved from https:\&\&doi.org \&10.1002\&ldr.894

20. Sulieman HM \& Elagib NA:(2012) Implications of climate, land-use and land-cover changes for pastoralism in eastern Sudan. J Arid Environ (85): 132-141 .Retrieved from https: \&\&doi.org\&10.1016\&j.jaridenv.2012.0 5.001 